\title{
体外循環下開心術における活性化血小板の \\ 変動とその意義
}

一抗 GMP-140抗体 2 T 60 を用いた flow cytometry による解析一

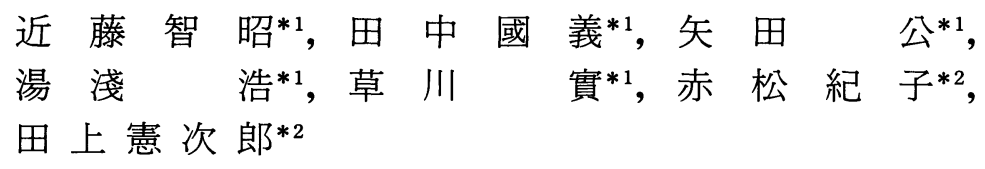

Activation of the Circulating Platelets During

Cardiopulmonary Bypass

-Flow Cytometric Analysis Using an Anti-GMP-140

Monoclonal Antibody (2 T 60) -
Chiaki KONDO*1, Kuniyoshi TANAKA*1, Isao YADA*1, Hiroshi YUASA*1, Minoru KUSAGAWA*1, Noriko AKAMATSU*2, Kenjiro TANOUE*2

Key words : cardiopulmonary bypass (CPB), open heart surgery, platelet activation, GMP-140, flow cytometry

Appearance of the activated platelets and their behaviors during cardiopulmonary bypass (CPB) surgery were studied in 21 adult patients undergoing coronary artery bypass grafting or valve replacement. Sampled blood was immediately fixed with 1\% paraformaldehyde. The isolated and washed platelets were incubated with $5 \mu \mathrm{g} / \mathrm{ml}$ of $2 \mathrm{~T} 60$ (antiGMP-140 monoclonal antibody) and then with FITC-conjugated anti-mouse IgG for flowcytometric analysis.

Mean fluorescence intensity of the $2 \mathrm{~T} 60$-stained platelets was $19.5 \pm 5.9$ at pre-CPB and increased significantly $(\mathrm{p}<0.01)$ during $\mathrm{CPB}$ and reached the maximal level $(26.2 \pm 9.2)$ at 120 min of CPB. After the end of CPB, it decreased and on the first postoperative day it returned to the pre- $\mathrm{CPB}$ value. Immunofluorescence histograms of $2 \mathrm{~T} 60$-stained platelets showed a main population composed of the inactivated GMP-140-negative platelets (channel number less than 20) with a small population of the activated GMP-140-positive platelets on the right slope shoulder of the main (channel number greater than 20 ) before $\mathrm{CPB}$. After the beginning of $\mathrm{CPB}$, the activated platelets rapidly increased and formed another distinguishable population of activated platelets. In 8 of 21 patients, the peak

*1 三重大学医学部胸部外科〔 gery, Mie University School of Medicine. 2-174 Edobashi, Tsu, Mie, 514, Japan.

*2 東京都臨床医学総合研究所循環器病研究部〔 cular Research, The Tokyo Metropolitan Institute of Medical Science. 3-18-22 Honkomagome, Bunkyoku, Tokyo, 113, Japan. 受付: 1992. 10.26, 受理 : 1993. 2.10. 
height of the population of the activated GMP-140-positive platelets was higher than or equal to that of the inactivated GMP-140-negative platelets. However, the peaks of the activated platelets did not shift to the right side, i.e., the channel number of the peak remained at the same immunofluorescent intensity, suggesting that there is a certain limit in the activation of the circulating platelets during CPB and the platelets activated beyond the limit may be removed from the circulation.

In conclusion, platelets are activated during $\mathrm{CPB}$ and the platelets activated beyond a certain limit are removed from the circulation, resulting in thrombocytopenia after CPB.

\section{はじめに}

体外循環下開心術においては人工心肺（cardiopulmonary bypass, (CPB)) 回路内面と血 液との接触や凝固線溶機能㝋進などに伴い, 血 小板の活性化, あるいは機能異常が引き起こさ れ, 術後の止血異常の原因となると考えられて いる1).しかし，その詳細な機序については今な お不明な点が少なくない.

血小板 $\alpha$ 顆粒膜に存在する糖蛋白 GMP-140 は, 血小板活性化反応の一つとしての放出反応 に伴って表面膜上に移動する糖蛋白であり, こ の GMP-140に対して作成されたモノクローナ ル抗体 2 T $60^{22 \sim 4)}$ は, ヒトまたは家兔の活性化 血小板に特異的に結合することができる.

本研究は血小板活性化反応の一つとして分泌 (放出) 反応を経過した血小板を, モノクローナ ル抗 GMP-140 抗体 (2 T 60) 結合可能なものと して検出することにより，体外循環下開心術に おける血小板活性化の動態を明らかにすること を目的として行った。

\section{I. 対象と方法}

\section{1. 対象}

当科にて施行した体外循環下開心術症例 21 例（冠動脈バイパス術 15 例，弁置換術 6 例）を 対象とした. 内訳は男性 14 例, 女性 7 例, 年齢 は 24 から 77 歳 (平均 55.8 歳) であった.

\section{2. 体外循環方法}

体外循環は全例膜型肺 (MERA 社製, メラエ クセランバインディング HPO-25 H または Medtronic 社製，MAXIMA-1380）とローラー ポンプを組み合わせて施行した。膜型肺の材質
はポリプロピレンで, 回路チューブは塩化ビニ ル製を用いた。回路充填には $20 \%$ D-mannitol 5 $\mathrm{ml} / \mathrm{kg}, 6 \%$ hydroxyethylstarch (Hespander (B) $5 \mathrm{ml} / \mathrm{kg}$ に乳酸リンゲルを加えて全量を $1,800 \mathrm{~m} l$ とし, 充填液 $500 \mathrm{~m} l$ に対し, 抗凝血薬 としてヘパリン $10 \mathrm{mg}$ を加えた. カニュレーシ ヨン前にヘパリン $3 \mathrm{mg} / \mathrm{kg}$ を右心耳から全身 投与し，体外循環中は ACT を 400 秒以上に保 った。体外循環終了後, 投与へパリンの 1.5 倍 量の硫酸プロタミンにてヘパリンを中和した。 体外循環灌流量は $2.4 \mathrm{l} / \mathrm{min} / \mathrm{m}^{2}$ を目標とし, $25 \sim 28^{\circ} \mathrm{C}$ の中等度低体温下に開心術を行った。 平均体外循環時間は $154 \pm 38$ 分であった。

\section{3. 採血および測定}

採血は術前, 体外循環開始後 5 分, 60 分, 120 分, 体外循環終了後 1 時間, 3 時間, 術後 1 日目 (体外循環終了後 16〜20 時間) の時点で，橈骨 動脈留置カテーテルまたは体外循環回路送血側 から行った. 血小板数の測定は自動血球測定器 (東亜医用電子, E 4000, 神戸) にて行い, へマ トクリット值で補正した。活性化血小板の検出 は次のように施行した。 ACD 液 1 量を含むプ ラスチック注射筒に 6 量の血液を採取, ゆっく りと 3 回転倒混和し, 直ちに等量の $2 \%$ paraformaldehyde (TAAB Laboratories. Reading, Berks.) と混合し, 室温にて 15 分間固定し た. $120 \mathrm{~g}$ 室温で 15 分間遠心し platelet-rich plasma (PRP) を集め,さらに PRPを $1200 \mathrm{~g}$ 室温で 15 分間遠心し pellet とした。これを phosphate-buffered saline (PBS, pH 6.5) に 浮遊させた後, $1,000 \mathrm{~g}$ で 10 分間室温にて 2 回 洗浄, PBS (pH 7.4)に再浮遊させ解析まで $4^{\circ} \mathrm{C}$ で保存した.血小板 $1 \times 10^{8} / \mathrm{m} l$ に対し, 2 T 60 抗 
体を最終濃度 $5 \mu \mathrm{g} / \mathrm{m} l$ になるように加え，氷冷 中にて 1 時間睬置, 洗浄後, FITC 標識ヤギ抗 マウス Ig (Becton Dickinson Immunocytometry Systems, San Jose, CA）と反 応させた後に, flow cytometry (FACScan, Becton Dickinson Immunocytometry Systems, Mountain View, CA, 以下 FC) にて解析 した. 2 T 60 抗体との反応, FCによる解析は血 小板の固定，洗浄後， 48 時間以内に行った. 予 備実験にて同一検体を種々の保存時間で解析し たところ，5 日以内であれば測定結果に差を認 めないことを確認している. 2 T 60 抗体のヒト 血小板への結合が，活性化に依存していること を明らかにするために，洗浄ヒト血小板を種々 の濃度のトロンビンで 10 分間刺激し, 固定, 洗 浄後, $2 \mathrm{~T} 60$ 抗体と反応させた時の FCにおけ るヒストグラムを Fig. 1に示す．ヒストグラム 上で 2 T 60 結合の peak が右方へ移動するこ とにより，血小板表面の GMP-140 の発現が, トロンビンの濃度依存性に増加することが証明 された。

陰性対照としては，2T60のかわりに正常マ ウス $\operatorname{IgG}$ を用いた。

各測定值は mean $\pm \mathrm{SD}$ で表し, 統計学的処理 は Wilcoxon test または Student's t test にて 行い, $\mathrm{p}<0.05$ を有意差ありとした。

\section{II. 結 果}

\section{1. 血小板数}

ヘマトクリットで補正した血小板数は，体外 循環開始前を $100 \%$ とすると，5 分後にはすで に有意に $(\mathrm{p}<0.01)$ 減少し, 120 分後 $74.3 \pm$ $14.6 \%$ ，体外循環終了 1 時間後 $60.6 \pm 21.2 \%$ とさらに減少し, 術後 1 日目に最低值 $49.1 \pm$ $18.0 \%$ に達した。 その後は増加し, 術後 7 日目 には $136.7 \pm 52.1 \%$ まで反跳した（Fig. 2)。

\section{2. 活性化血小板}

(1)Mean Channel による検討 : 流血中の血小 板への 2 T 60 の結合度，すなわち GMP-140の 血小板表面への発現を FC の蛍光強度における Mean Channel で表現すると，術前は 19.5士 5.9 で，体外循環開始 $5 ， 60 ， 120$ 分後にはそれ ぞれ $21.1 \pm 6.0,24.2 \pm 8.9,26.2 \pm 9.2$ (いずれ

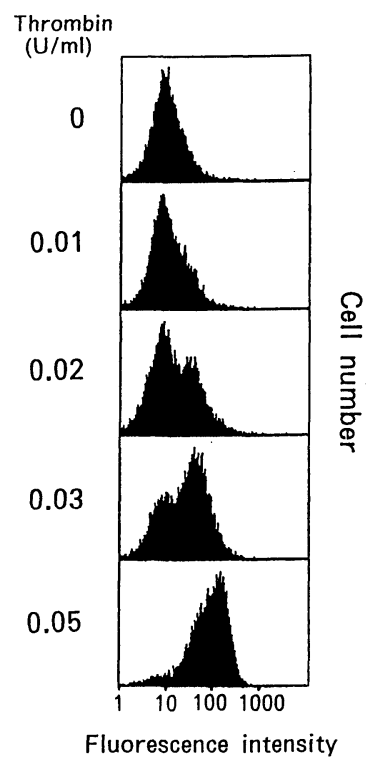

Fig. 1 Flow cytometric analysis of thrombin-activated platelets. Platelets activated with thrombin showed dosedependent increases in the expression of GMP-140 (2 T 60 antigen)

も $\mathrm{p}<0.01 ）$ と漸増し，体外循環終了後は低下 傾向を示すものの，体外循環開始 5 分から終了 1 時間後まで有意 $(\mathrm{p}<0.01)$ の高值を示した。 しかし，体外時間後 3 時間には $20.4 \pm 6.0$ まで 低下し, 術後 1 日目には $19.3 \pm 5.3$ と前值に復 した (Fig. 3).

(2)陽性率による検討 : 各 sampling point に おいて，2 T 60 のかわりに IgG を結合させた血 小板を陰性対照とし，FC のヒストグラムで蛍 光強度が弱いほうからの度数が $90 \%$ となる部 位に cut off line を設定し，それより蛍光強度 の強い部分を陽性として，全体に対するパーセ ントで表現した。術前には $29.7 \pm 8.4 \%$ で，体 外循環開始 $5,60,120$ 分後にはそれぞれ $35.2 \pm$ $10.2 \% ， 41.0 \pm 11.2 \% ， 41.5 \pm 10.1 \%$ (いずれ も $\mathrm{p}<0.001)$ と漸増し，体外循環終了後は低下 傾向を示し, 術後 1 日目には $30.5 \pm 8.3 \%$ とほ ほ前值に復した。 mean channel による検討と 同様に体外循環開始 5 分から終了 1 時間後ま で，2 T 60 結合陽性血小板の有意 $(\mathrm{p}<0.001)$ な増加を認めた。

(3)ヒストグラムのパターンによる検討 : Fig. 


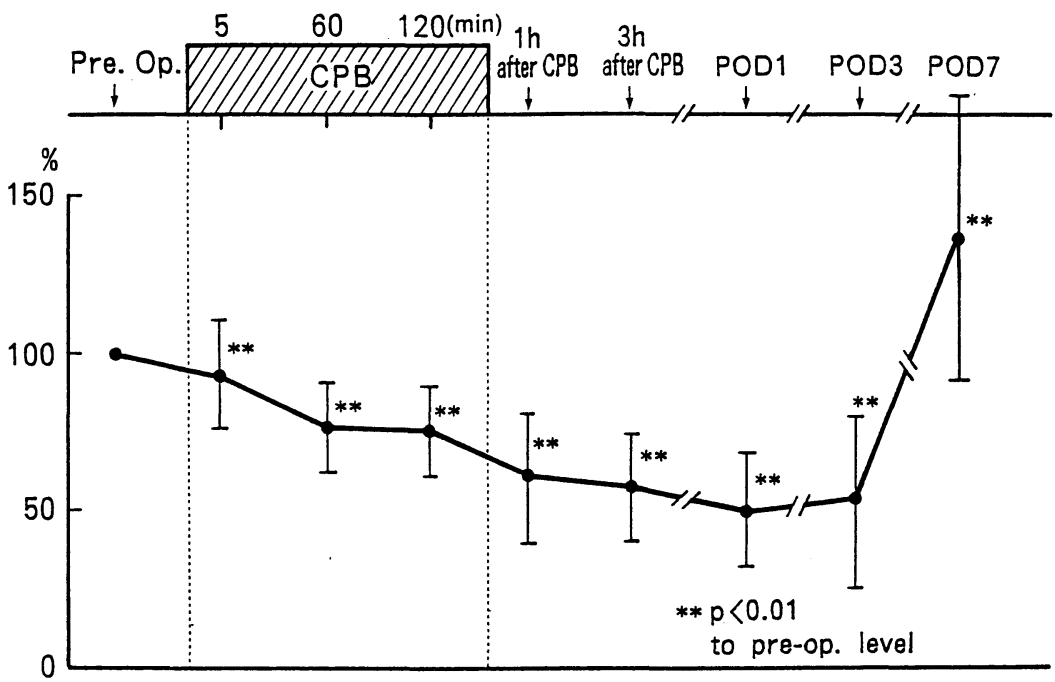

Fig. 2 Changes in platelet counts during open heart surgery.

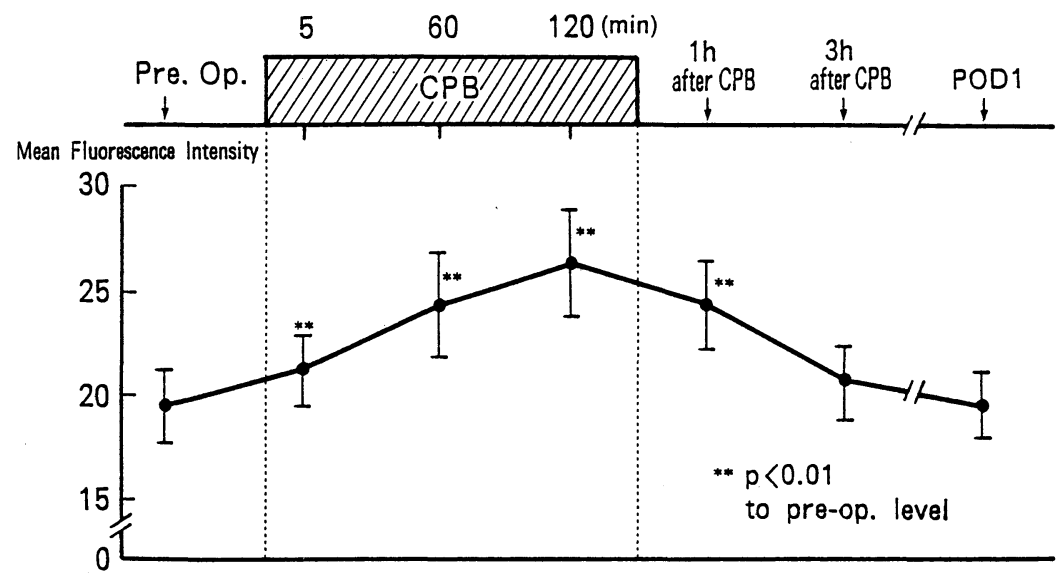

Fig. 3 Changes in mean fluorescence intensity of the $2 \mathrm{~T} 60$-stained platelets on flow cytometry. The mean fluorescence intensity of the $2 \mathrm{~T} 60$-stained platelets increased significantly during $\mathrm{CPB}$ and reached the maximal level at 120 minutes of CPB. After the end of CPB, it decreased and on the first postoperative day it returned to the pre-CPB value.

4は FC における血小板のヒストグラムを示し たものである. 2 T 60 結合陰性の血小板の峰の 中心は Channel Number (以下 $\mathrm{CN}$ ) の 6〜10 に存在する。一方， 2 T 60 結合陽性の血小板の 峰は CN 30〜50 に形成された. Fig. $4 \mathrm{~A}$ は陽 性血小板の峰の形成が陰性血小板の峰よりも低 值にとどまった症例 (38 歳, 男, 冠動脈バイパ ス術)，B は陽性血小板の峰が陰性血小板の峰 と同じ高さになった症例 (65 歳, 男, 冠動脈バ イパス術), C は陽性血小板の峰が陰性血小板の
峰より高くなった症例 (41 歳, 女, 僧帽弁置換 術)のヒストグラムを表す.今回検討した 21 例 を上記の 3 パターンに分類すると， A : 13 例, $\mathrm{B}: 3$ 例, $\mathrm{C}: 5$ 例であった. 程度の差はあるもの の，いずれも陽性血小板の峰は体外循環中しだ いに高くなり, パターン A を呈した症例の中に も明確な 2 峰性を呈する症例もあり，これらを 含めると全症例の半数以上で陽性血小板の明確 な峰が検出された。しかし陽性血小板の峰の位 置を詳細に検討すると，この峰の位置 $(\mathrm{CN})$ は 


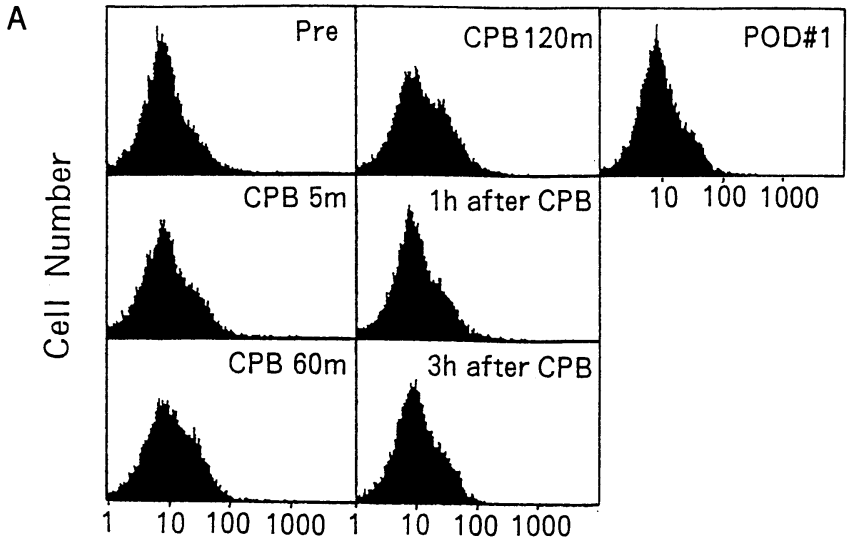

Log Fluorescence

B

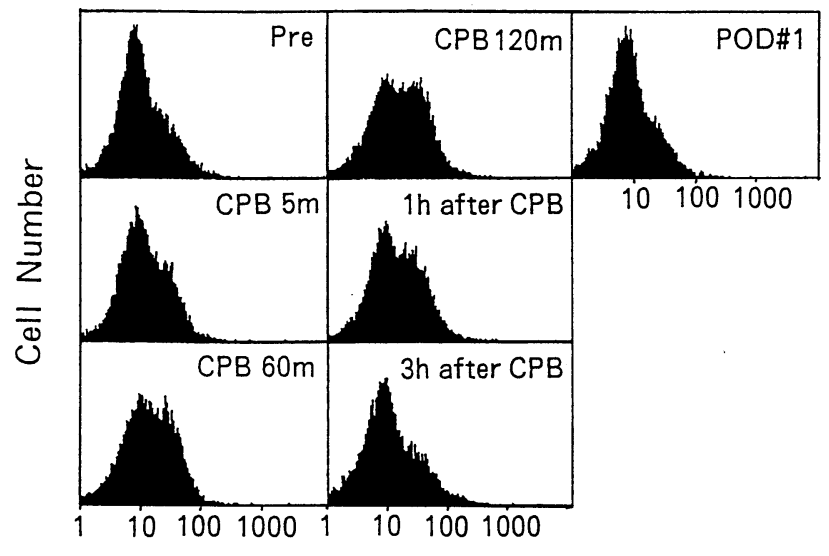

Log Fluorescence

C

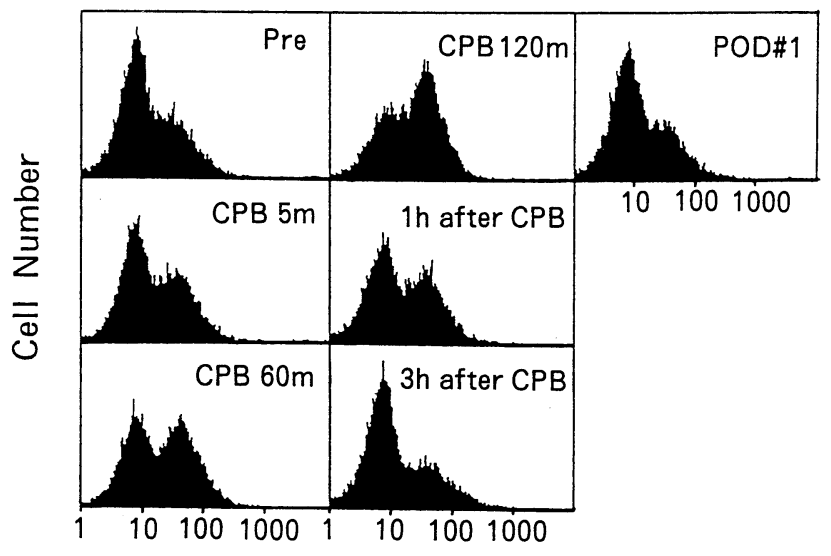

Log Fluorescence
Fig. 4 Immunofluorescence histograms of $2 \mathrm{~T} 60$ - stained platelets during open heart surgery.

Immunofluorescence histograms of $2 \mathrm{~T} 60$ - stained platelets showed a main population composed of the inactivated GMP-140-negative platelets (channel number less than 20) with a small population of the activated GMP-140-positive platelets on the right slope shoulder of the main (channel number greater than 20) before $\mathrm{CPB}$. After the beginning of $\mathrm{CPB}$, the activated platelets rapidly increased and formed another distinguishable population of the activated platelets.

A : Thirty-eight years old male, undergoing coronary artery bypass grafting (CABG). The peak height of the population of the activated platelets was lower than that of the inactivated platelets.

B : Sixty-five years old male, undergoing CABG. The peak height of the population of the activated platelets was equal to that of the inactivated platelets.

$\mathrm{C}$ : Forty-one years old female, undergoing mitral valve replacement. The peak height of the population of the activated platelets was higher than that of the inactivated platelets.

Even in the case $\mathrm{B}$ or $\mathrm{C}$, the peaks of the activated platelets did not shift to the right side, i.e., the channel unmber of the peak remained at the same immunofluorescence intensity. 
症例間により若干の差がみられたが，同一症例 においては CPB の経過において, 峰の高低に かかわらずほぼ一定の位置にとどまっていた。 さらに, パターン C の様に体外循環開始 120 分 後に陽性血小板の峰が陰性血小板の峰よりも高 くなるような場合でも, 陽性血小板の峰の $\mathrm{CN}$ がさらに右方へ移動することはなかった。

\section{III. 考 察}

体外循環は開心術の補助手段として必須のも のであるが，体外循環中は血液と回路内面との 接触をはじめとする種々の機序により, 凝固線 溶系, 血小板, 補体系, 顆粒球などの活性化が 引き起こされ，これらがさまざまな合併症の発 生に大きく関与すると考えられる(5) 7).とりわ け血小板に招来される変化は, 術後の止血異常 の原因となると考えられている ${ }^{8)}$.一方, 近年, 血小板活性化の機構の研究が進み, 血小板表面 受容体として, 血小板膜糖蛋白の構造, 機能が 明らかにされてきた9).

体外循環に伴う血小板の活性化は, 従来, 血 小板 $\alpha$ 顆粒内容物である $\beta$-thromboglobulin ( $\beta$ TG) p platelet factor 4 (PF 4) の血漿中 濃度の増加で示されることが多いが10)11), 果し てそれらの増加が活性化に伴う放出反応のみを 示すものかどうかは問題のあるところであり， 体外循環のように機械的刺激のかかる状況下に おいては, 物理的破壊に伴う血漿中への遊離と いう可能性も否定できない. 今回我々は, 個々 の血小板におけるその活性化状態を $\alpha$ 顆粒膜 糖蛋白の GMP-140 の血小板表面への発現の程 度でとらえた。その結果, 体外循環の経過に伴 い, 流血中に 2 T 60 抗体を結合し得る血小板, すなわち GMP-140 を表面に発現する血小板が 増加することを明らかにした。このことは体外 循環に伴って血小板が何らかの機序により分泌 反応，いわゆる活性化を経過したことを明確に 示している. Rinder ら ${ }^{12) 13)} も$, 体外循環におけ る血小板の活性化を同様に GMP-140 の血小板 表面への発現という面から検討し, 活性化血小 板の増加を報告しているが, 彼らは実際の FC のヒストグラムのパターンについては詳細に検 討していない.
そこで，われわれは FC のヒストグラムのパ ターンによる血小板活性化の状態を検討した。 まず，体外循環中の血小板のヒストグラムで， 活性化され GMP-140を発現した血小板と，そ うでないものの二つの population が見られた. この二つの population の形成の正確な機序に ついては，なお検討の余地があるが，一つの理 由として，血小板の中で活性化され易い血小板 とそうでないものとが存在し，その反応性の違 いから FC のヒストグラムが二峰性を呈した可 能性も考えられた. Rinder ら ${ }^{12)}$ は抗 GMP-140 抗体を反応させた血小板の contour graph を示 しているが, one population であった。われわ れとの相違の原因は不明であるが，体外循環装 置や手技を含めた手術全体の違いや，体外循環 時間の違いが考えられた。また，用いた抗 GMP-140 モノクローナル抗体も異なり,われわ れが用いた抗体 (2 T 60) の方が血小板表面に発 現された GMP-140をより感度良く検出し得た との可能性も推察された.

次に，体外循環開始 1 または 2 時間後には, 2 T 60 陽性の血小板の峰が，2 T 60 陰性の血小 板の峰と同程度 (21 例中 3 例) か，あるいはそ れよりも高くなるもの (21 例中 5 例) も見られ， 体外循環中には広範に，かつ強度に血小板への 刺激が生じていることが示唆された。しかしな がら，2 T 60 陽性の血小板が最大量に達した時 点 (体外循環開始 1 または 2 時間)においても, 陽性血小板の峰の $\mathrm{CN}$ は症例によりほほ一定 であり， CN の増大（峰の右方移動）が生じな かったことは注目された。このことは体外循環 の経過とともに血小板表面に GMP-140の発現 している血小板数は増大するが，流血中では 個々の血小板における GMP-140の発現量には 一定の限界があると解釈される。

一方，実験的に in vitro でトロンビン濃度を 変えて血小板を刺激した場合には，濃度依存性 に 2 T 60 陽性の血小板が増加するとともに, $\mathrm{FC}$ のヒストグラム上で陽性血小板の峰の $\mathrm{CN}$ が増大する.すなわち峰の位置が右方へ移動し, 無刺激血小板とはそのすそ野と僅かにしか重な らない程に右方へ移動する (Fig. 1)。すなわ ち, 体外循環施行中の流血中に存在する血小板 
の GMP-140 の発現は, 最大限まで達していな いと考えられる。体外循環中の in vivo で GMP-140 の発現量に限界がみられた原因とし て，(1)体外循環による刺激が in vitro でおこな ったトロンビン刺激 $(0.05 \mathrm{U} / \mathrm{m} l)$ に比して軽 度であるか，あるいは(2)限界を越えて活性化さ れた血小板は,生体内では循環し得なくなるか, という二つの可能性が考えられる。

次に，体外循環終了後， 2 T 60 陽性の血小板 の峰は速やかに低下するが，この活性化血小板 の全てが流血中から除去されるのではないと考 えられる.それは，Fig. 2 の血小板数の変動を みると，体外循環開始後 1 時間は急速に減少す るが，体外循環を続けてもそれ以後の 1 時間は あまり減少していない。さらに，体外循環開始 2 時間時のヒストグラムで $2 \mathrm{~T} 60$ 陽性血小板 が陰性血小板よりも多いか同じ程度の症例 8 例 (Fig. 4 B，C に相当する) において，体外循環 終了 1 時間後の血小板数は体外循環開始 2 時間 の血小板数の約 $75 \%$ にとどまっていたが，も し全活性化血小板が流血中から除去されるなら $50 \%$ 程度まで低下するはずである。これらのこ とより,GMP-140 を表面に発現するに至った血 小板の一部は，体外循環終了後には何らかの機 序で修復を受けて流血中に存在し続けている可 能性が示唆された。この機序についての解明は, 今後，検討が必要と考えられる。

最近，GMP-140 に対する ligand が，さまざ まな細胞表面に存在することが明らかにされて

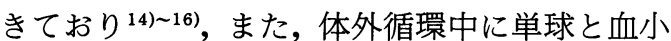
板の接着が増加するという報告もみられる ${ }^{17)}$. このことは，生体内においては，ある限界を越 えて活性化され, GMP-140をより多く膜表面に 持つに至った血小板は，これら GMP-140の ligand を持つ流血中の好中球，単球などと接着 し, 一層, 網内系で貪食され易くなる可能性も 推測される。これは，一定限界以上活性化を受 けた血小板が，流血中から除去される過程と体 外循環に伴っておこる血小板数の低下のメカニ ズムに対し，ひとつの説明を与えるものかも知 れないと考えられた。

\section{結語}

体外循環施行時の流血中の活性化血小板の検 出を，抗 GMP-140 抗体 2 T 60 を用いて行っ た.

(1)体外循環に伴って GMP-140 が血小板表面 に増加したことから，体外循環により血小板の 放出反応を含む活性化が生じていることが確認 された。

(2)流血中の血小板の GMP-140 の発現量には 限界が見られた。

\section{文献}

1) Tanaka K., Takao M., Yada I., Yuasa H., Kusagawa M. and Deguchi K. : Alterations in coagulation and fibrinolysis associated with cardiopulmonary bypass during open heart surgery. J. Cardiothorac. Anesth., 3:181 188, 1989 .

2）田上憲次郎，赤松紀子, 鈴木英紀, 片桐康博, 山崎博 男, 藤本 司, 福田祐幹, 小野沢康輔 : 活性化血小板 の検出一抗 GMP-140 抗体を中心に一. 日本臨床, 50 : 330 335, 1992.

3) Akamatsu N., Yamaguchi A., Katagiri Y., Suzuki H., Tanoue K. and Yamazaki H.: A novel monoclonal antibody specific to activated platelets. Thromb. Haemostas., 62 : 250, 1989.

4) Tanoue K., Akamatsu N., Katagiri Y., Fujimoto T., Kurokawa T., Iwasa S., Koike M., Kawasaki H., Suzuki H. and Yamazaki H. : Detection of in-vivo activated platelets in experimental cerebral thrombosis in rabbits, studies by a new monoclonal antibody ' $2 \mathrm{~T} 60$ ' specific for the activated platelets of both humans and rabbits. Platelets, 4 : 31 39, 1993.

5) Tanaka K., Tani K., Morimoto T., Yada I., Yuasa H. and Kusagawa M. : Hemostatic analysis for patients undergoing open heart surgery by molecular marker assays-with special reference to thrombin-antithrombin III complex and $\alpha 2$ plasmin inhibitor-plasmin complex. Artif. Organs Today, $2: 127 \sim 135,1992$.

6) Andrade JD., Coleman DL., Didisheim P., Hanson SR., Mason R. and Merrill E.: Blood material interaction-20 years of frustation (Panel Con- 
ference). Trans. Am. Soc. Artif. Int. Organs, 27 : $659 \sim 662,1981$.

7) Stratta P., Canavese C., Costa P., Martini C., Festa T., Bulla A. and Vercellone A. : Biological stress induced by extracorporeal circulation : Comparsion between cardiopulmonary bypass, hemodialysis and plasma exchange. Trans. Am. Soc. Artif. Int. Organs, 30 : 502 507, 1984.

8) Woodman RC. and Harker LA. : Bleeding complication associated with cardiopulmonary bypass. Blood, $76: 1680 \sim 1697,1990$.

9）山崎博男 : 血栓準備状態としての血小板活性化と膜 糖蛋白. 最新医学, $45:$ 1306 1312, 1990.

10) Harker LA., Malpass TW., Branson HE., Hessel EA. and Slichter SJ.: Mechanism of abnormal bleeding in patients undergoing cardiopulmonary bypass: Acquired transient platelet dysfunction associated with selective $\alpha$-granule release Blood, 56 : 824 834, 1980.

11) Mezzano D., Aranda E., Urzua J., Lema G. Habash J., Irarrazabal MJ. and Pereira J : Changes in platelet $\beta$-thromboglobulin, fibrinogen, albumin, 5-hydroxytryptamine, ATP, and ADP during and after surgery with extracorporeal circulation in man. Am. J. Hematol., 22 : 133
〜142, 1986.

12) Rinder CS., Bohnert J., Rinder HM., Mitchell J., Ault K. and Hillman R. : Platelet activation and aggregation during cardiopulmonary bypass. Anesthesiology, $75:$ 388 393, 1991.

13) Rinder CS., Mathew JP., Rinder HM., Bonan J., Ault KA. and Smith BR. : Modulation of platelet surface adhesion receptors during cardiopulmonary bypass. Anesthesiology, $75: 563 \sim 570$, 1991.

14) De Bruijne-Admiraal LG., Modderman PW. Von dem Borne AEGKr. and Sonnenberg A.:Pselectin mediates $\mathrm{Ca}^{2+}$-dependent adhesion of activated platelets to many different types of leukocytes: Detection by flow cytometry. Blood, $80: 134 \sim 142,1992$.

15) McEver RP.: Leukocyte interactions mediated by selectins. Thromb. Haemostas., 66:80 87, 1991.

16) Springer TA. and Lasky LA. : Sticky sugers for selectins. Nature, 349 : 196 197, 1991.

17) Rinder CS., Bonan JL., Rinder HM., Mathew J., Hines R. and Smith BR.: Cardiopulmonary bypass induces leukocyte-platelet adhesion. Blood, $79:$ 1201 1205, 1992. 